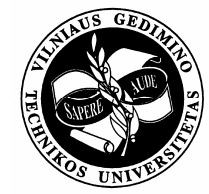

\title{
APPLICATION OF COMPUTER SIMULATION TO CONSTRUCTION OF INCREMENTAL LAUNCHING BRIDGES
}

\author{
Mohamed Marzouk ${ }^{1}$, Hisham Zein El-Dein ${ }^{2}$, Moheeb El-Said ${ }^{3}$ \\ Dept of Structural Engineering, Faculty of Engineering, Cairo University, Giza, Egypt. \\ E-mail: ${ }^{1}$ mm_marzouk@yahoo.com; ${ }^{2} h \_z e i n e l d e i n @ y a h o o . c o m ;{ }^{3}$ elsaid1204@yahoo.com
}

Received 21 Nov 2005; accepted 24 May 2006

\begin{abstract}
Construction of bridges is associated with uncertainties that rise due to unavailability of resources, equipment breakdown and/or working environment. Bridge construction techniques can be grouped into six main categories: 1) castin-situ on false work, 2) cantilever carriage, 3) stepping formwork, 4) launching girder, 5) pre-cast balanced cantilever, and 6) incremental launching. The latter technique is characterised by minimising the use of falsework. Further, the fabrication and casting of bridge segments are executed at a stationary location, named casting yard (which includes several facilities), deck form, concrete mixing unit, and pumping system. This paper presents a special purpose simulation model to capture the uncertainty associated with bridge construction. The model accounts for the interaction between the different involved resources in construction of bridges using incremental launching technique. The paper describes two methods (single form and multiple forms) of execution used for the segments fabrication. The proposed simulation model utilises STROBOSCOPE as a simulation engine and is coded by Visual Basic 6.0. An actual case study is presented to illustrate the capabilities of the developed model and validate its performance.
\end{abstract}

Keywords: planning, bridge construction, computer simulation, incremental launching bridges, scheduling, uncertainties.

\section{Introduction}

Computer simulation is a powerful tool for the analysis of new and existing systems. A project simulation uses a model that translates the uncertainties specified at a detailed level of the project into their potential impact on project objectives [1]. Analysis of projects using simulation is performed for several purposes [2]. These include: evaluation of a proposed system; comparison between alternative proposals; prediction of system performance under different conditions; sensitivity analysis to determine the most significant factors affecting the performance of a system; optimization to determine the best overall response of a system; functional relations to recognize any relationship among the system significant factors; and bottlenecks analysis to identify the factors that cause system delays.

Computer simulation is one of the techniques that has been used to model uncertainties involved in construction operations [3]. Although simulation is a powerful tool for modelling construction operations, the application of simulation is still limited in the construction domain. This has generally been attributed to the difficulty in learning and applying simulation languages to industry [4-6].

Typically, modelling utilising simulation can be applied either in a general or special purpose simulation environment. General purpose simulation (GPS) is based on formulating a simulation model for the system underinvestigation, running the simulation and analysing the results to decide whether the system is acceptable or not. In case of being unacceptable, the process is reiterated and a new alternative system is considered. Various GPS software systems have been developed for a wide range of industries: AweSim [7] and GPSS/H [8]; for construction: Micro-CYCLONE [9] and STROBOSCOPE [10]. Special purpose simulation (SPS) is based on creation of a platform or a template for a specific domain of application $[11,3]$. The steps for simulation, in this case, are the same as in the GPS case, except for the first step (construct simulation model), since the platform already includes the characteristics and behaviour of the system under study. Also, the modification is limited to the input parameter(s) of a pre-defined system and not to the characteristics and behaviour of the system.

This paper presents a special purpose simulation model, dedicated to assist contractors in planning the segmental bridge construction using incremental launching technique. It utilises STROBOSCOPE as a simulation engine to model the activities inherited in construction of bridges' decks using incremental launching technique. STROBOSCOPE simulation elements (Table 1) are used to model tasks involved in single form and multiple forms methods. These elements include Normal, Combi, Queue, Arc, and Fusion Queue [10]. The model is coded utilising Visual Basic 6.0. The following sections describe the developments made in the proposed incremental launching simulation model.

\section{Incremental launching construction technique}

Concrete bridges can be grouped, according to their type, into ordinarily reinforced and pre-stressed bridges. Ordinarily reinforced bridges cannot be used in long span 
Table 1. STROBOSCOPE simulation elements [10]

\begin{tabular}{cll}
\hline Nymbol & Name & \multicolumn{1}{c}{ Description } \\
\hline & CORMAL & $\begin{array}{l}\text { Unconstrained in its starting logic and indicates active processing of (or } \\
\text { by) resource entities }\end{array}$ \\
\hline & QUEUE & $\begin{array}{l}\text { Logically constrained in starting, otherwise similar to the NORMAL } \\
\text { work task modelling element }\end{array}$ \\
\hline
\end{tabular}

bridges. Pre-stressed bridges are utilized to overcome the above mentioned limitation of ordinary reinforced concrete bridges. With respect to the construction methodology, concrete bridges can be classified into six techniques: 1) cast-in-situ on false-work, 2) cantilever carriage, 3) flying shuttering, 4) launching girder, 5) pre-cast balanced cantilever, and 6) incremental launching. Several factors are considered when selecting the construction technique. These are: i) ingenuity of the designers and contractors, ii) resources availability, and iii) technical limitations. Incremental launching construction technique is characterised by using less temporary falsework and other expedients that are required during the construction as in the case of cast-in-situ on false-work technique [12]. It entails incremental fabrication of the superstructure at a stationary location, longitudinal movement of fabricated segment and casting of a new segment onto the one previously cast [13]. In other words, the procedure can be considered as a horizontal slip-form technique, except that the fabrication and casting occur at a stationary loca- tion (behind bridge's abutment). In incremental launching construction technique, there are two systems of launching. The first one has the jacks bearing on an abutment face and pulling on a steel rod, which is attached by launching shoes to the last segment cast. The second method is essentially a lift-and-push operation using a combination of horizontal and vertical jacks. Construction of a bridge deck using incremental launching technique involves three major operations: i) casting yard preparation, ii) segments fabrication, and iii) set-up of bridge deck. Fig 1 depicts the simulation network that represents bridge deck construction by incremental launching technique.

The casting yard is used to accommodate temporary facilities utilised for segment fabrication. These facilities include deck form, concrete mixing unit, and pumping system. The deck form consists of several components as shown in Fig 2. The second major operation in the incremental launching technique is segments fabrication, which involves fabrication cycles of equal segments that have a length equal to half or full length of the typical span. The

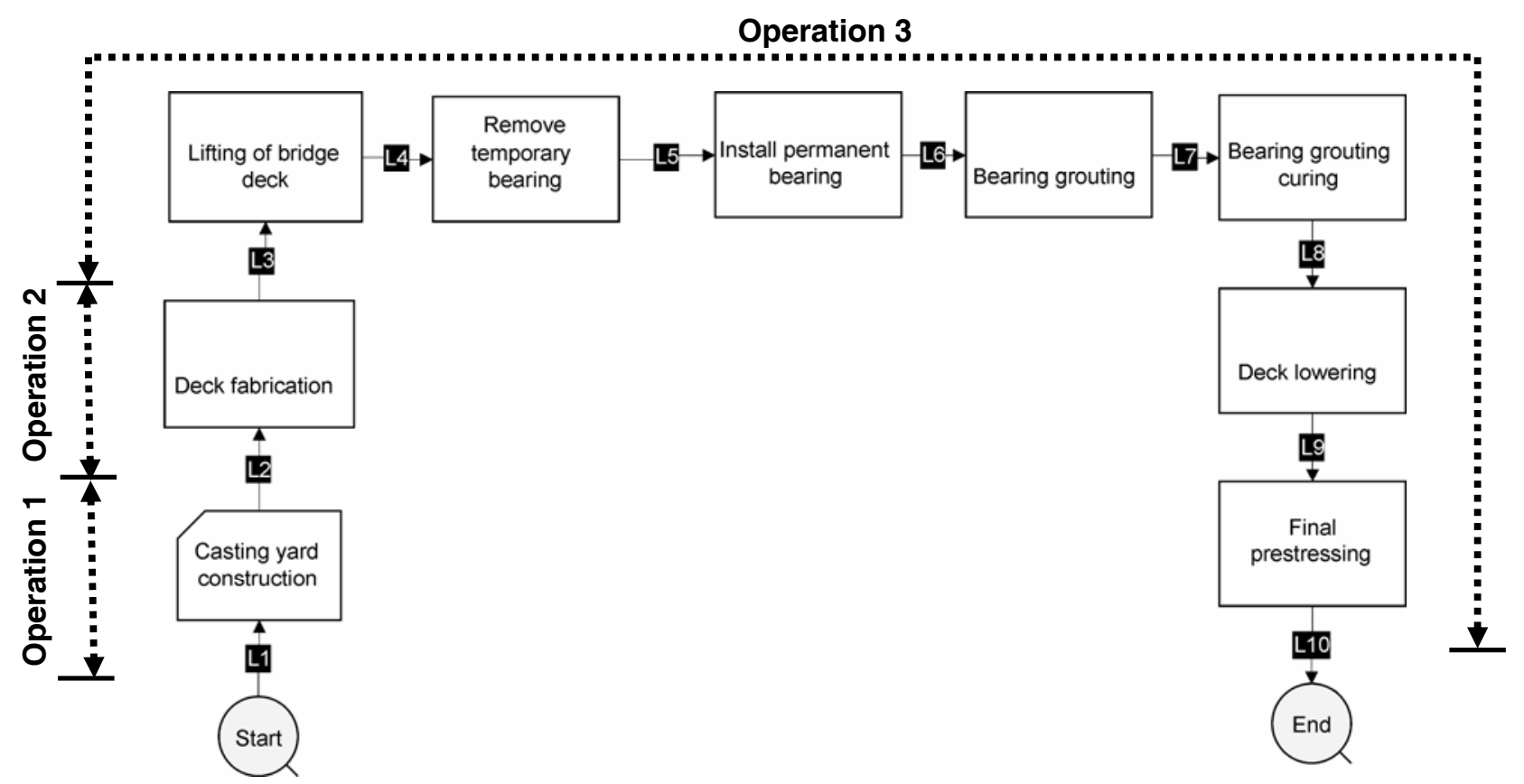

Fig 1. Simulation network for deck pushing technique 


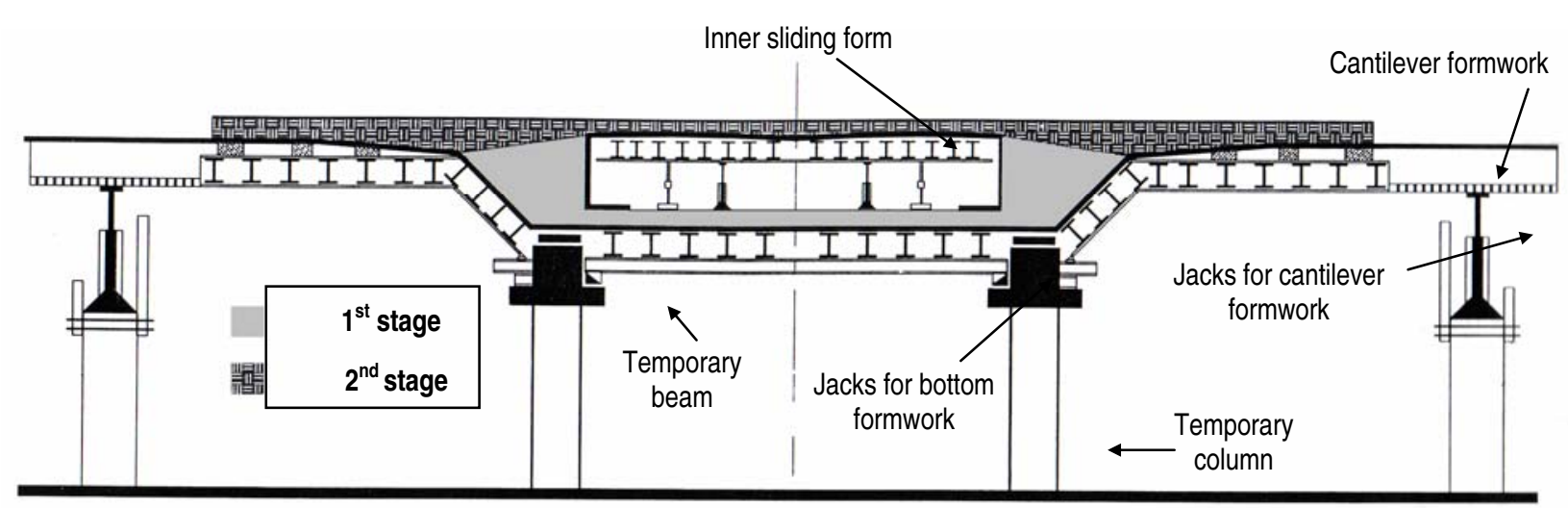

Fig 2. Components of deck form

fabrication cycle consists of three main processes which are broken down in successive tasks. The three processes are: 1) bottom flange and webs fabrication, 2) top flange fabrication, and 3) pre-stressing process. Segment fabrication can be performed either by a single form or multiple forms method. The set-up of bridge deck operation starts after the whole bridge deck is fabricated and pushed. It involves final pre-stressing of the bridge deck tendons, removal of temporary bearings, and permanent bearings installation. The following sections describe the modelling of the two methods (single form and multiple forms), used for segments fabrication in incremental launching technique.

\section{Modelling incremental launching using single form}

In this method of fabrication, three processes are executed in order to produce a single segment (Table 2). These are: i) bottom flange and webs fabrication, ii) top flange fabrication, and iii) incremental launching. Each process consists of a number of tasks, creating a total of 19 tasks. The first and second processes are accomplished successively in the same station. Before segment fabrication, the forms must be cleaned, raised and aligned. Reinforcement steel bars and pre-stressing ducts are placed for bottom flange and webs before they are poured. After sufficient curing period, inner sliding forms are used to cast the top flange (Fig 2). Then, the whole fabricated segment is pre-stressed and pushed.

Fig 3 depicts the simulation network, developed to represent segments fabrication operation using the single form method. Six resources are defined for this simulation network: four for labour crews, one for pump, and one named Segment to represent fabricated segment and to maintain tasks' logic. The logic and inference of the simulation is achieved by two tools: Arc elements and flow control statements. Arc elements are used to model the direction of resource entity flow between tasks. Flow

Table 2. Processes and tasks of single form method

\begin{tabular}{|c|c|c|}
\hline Process & Task code & Task description \\
\hline \multirow{7}{*}{ 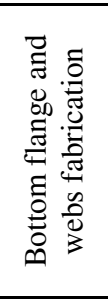 } & P1 & Cleaning, raising, aligning, and grading of forms \\
\hline & $\mathrm{P} 2$ & Placement of $1 / 2$ reinforcement for the bottom flange and webs $\left(1^{\text {st }}\right.$ stage rebar $)$ \\
\hline & P3 & Placement of ducts for the bottom flange and webs ( $1^{\text {st }}$ stage tendons $)$ \\
\hline & P4 & Finish reinforcement for the bottom flange and webs ( $1^{\text {st }}$ stage rebar $)$ \\
\hline & P5 & Erection of inner side forms \\
\hline & P6 & Concreting of the first phase ( $1^{\text {st }}$ stage casting $)$ \\
\hline & P7 & Curing of the first phase $\left(1^{\text {st }}\right.$ stage curing $)$ \\
\hline \multirow{7}{*}{ 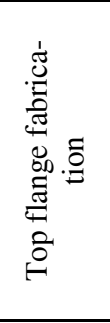 } & P8 & Removing of inner side forms \\
\hline & $\mathrm{P} 9$ & Pulling of inner top forms \\
\hline & P10 & Placement of $1 / 2$ reinforcement for the top flange ( $2^{\text {nd }}$ stage rebar $)$ \\
\hline & P11 & Placement of ducts for the top flange $\left(2^{\text {nd }}\right.$ stage tendons $)$ \\
\hline & P12 & Finish reinforcement for the top flange ( $2^{\text {nd }}$ stage rebar $)$ \\
\hline & P13 & Concreting of the second phase $\left(2^{\text {nd }}\right.$ stage casting $)$ \\
\hline & P14 & Curing of the second phase ( $2^{\text {nd }}$ stage curing $)$. \\
\hline \multirow{5}{*}{ 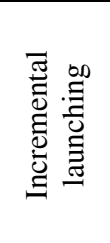 } & P15 & Tendons installation into pre-stressing ducts \\
\hline & $\mathrm{P} 16$ & Pre-stressing of tendons, first stage of longitudinal tendons and transversal tendons. \\
\hline & $\mathrm{P} 17$ & Dismantling and lowering of formwork \\
\hline & $\mathrm{P} 18$ & Surface check and finishing \\
\hline & P19 & Incremental launching \\
\hline
\end{tabular}




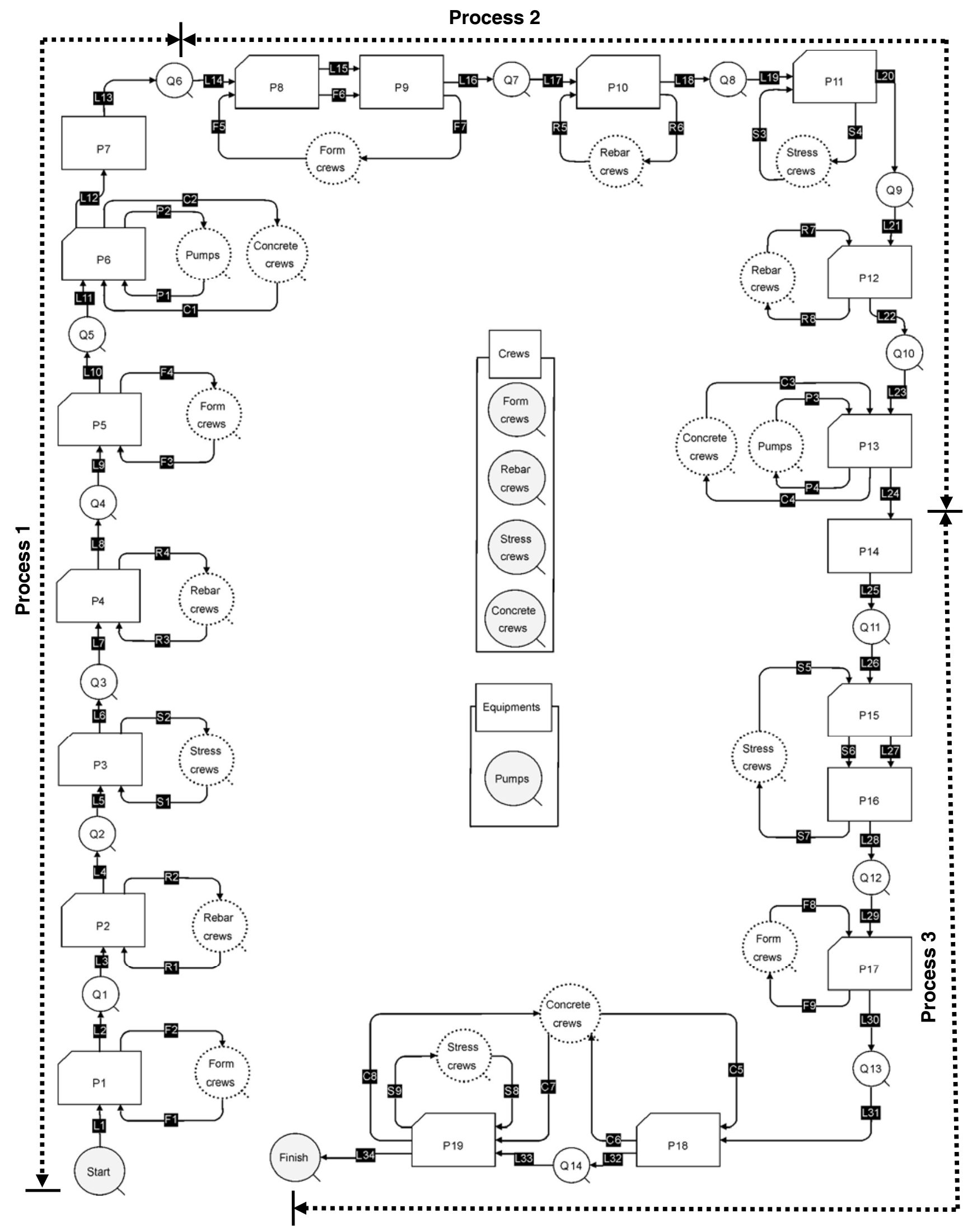

Fig 3. Simulation network for single form method 
control statements are used to control tasks' initiations, resources draw, resources release, and any conditional logical aspect that controls the operation. It is worth to note that the simulation network is developed as openloop despite the fact that the operation is repetitive. The network starts with a Queue named Start and ends with a Queue named Finish. The Start Queue is initiated with a quantity equal to the total number of segments using Segment resource as follows:

\section{INIT Start Nsegments;}

Segment resources are drawn from start Queue one by one. Each Segment resource goes through the nineteen tasks and then vanishes at Finish Queue. The cycle of a segment means has been cast, stressed, and pushed. Among the uses of flow control statements is to satisfy conditional statements as referred to earlier. For example, a flow control statement is used to prevent multiple segments from being executed simultaneously. The following SEMAPHORE statement assures that P1 Combi cannot start before finishing the current segment (i e, executing P19 Combi).

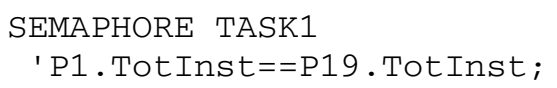

\section{Modelling incremental launching by multiple forms}

To speed up the construction by the incremental launching technique, two fabrication stages can be executed simultaneously using separate forms (Fig 4). The bottom flange and webs' bottom stubs of the first segment are erected and poured. After curing, prestressing of the first partial segment (ie bottom flange and bottom stubs of the webs) is performed. Subsequently, it is jacked and forwarded to the second form to fabricate the remaining part of the segment. As such, the form can be reused for the fabrication of the bottom flange for the second segment. This is a typical cycle in which two fabrication processes occur simultaneously: i) top flange of the second segment and ii) the bottom flange and webs' bottom stubs of the first segment. Once the reinforcement is set in two successive segments (typical cycle), the two segments are cast, cured, stressed, and jacked together. For incremental launching construction using multiple forms, bottom flange and webs and top flange fabrication are modelled in a single process, since they are fabricated simultaneously. Therefore, this method consists of two major processes which are deck fabrication and prestressing. These two processes have 17 tasks which are listed in Table 3. The simulation network for segments fabrication operation using multiple forms method is depicted in Fig 5.

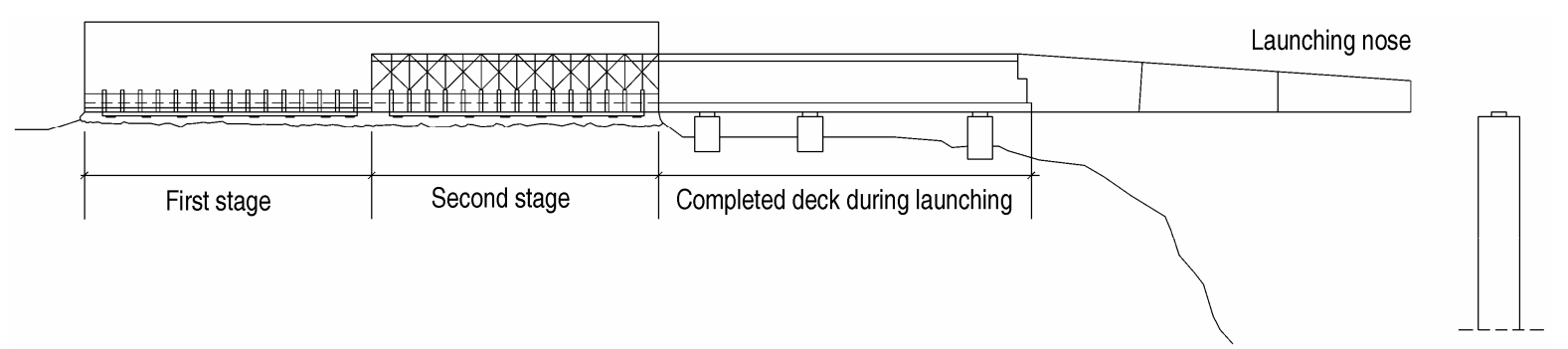

Fig 4. Segments fabrication by multiple forms method

Table 3. Processes and tasks of multiple forms method

\begin{tabular}{|c|c|c|}
\hline Process & Task code & Task description \\
\hline \multirow{12}{*}{ 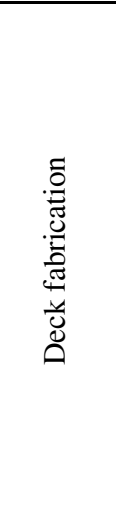 } & FClean & Cleaning, raising, aligning, and grading of the first form \\
\hline & FRebar1 & Placement of $1 / 2$ reinforcement for the bottom flange and bottom stubs of webs ( $1^{\text {st }}$ stage rebar) \\
\hline & FDucts & Placement of ducts for the bottom flange and bottom stubs of webs ( $1^{\text {st }}$ stage tendons $)$ \\
\hline & FRebar2 & Finish reinforcement for the bottom flange and bottom stubs of webs $\left(1^{\text {st }}\right.$ stage rebar $)$ \\
\hline & SideForms & Erection of inner side forms \\
\hline & Remove & Removing inner side forms \\
\hline & InnerForms & Pulling inner top forms \\
\hline & SRebar1 & Placement of $1 / 2$ reinforcement for the top flange and webs $\left(2^{\text {nd }}\right.$ stage rebar $)$ \\
\hline & SDucts & Placement of tendons for the top flange and webs $\left(2^{\text {nd }}\right.$ stage tendons $)$ \\
\hline & SRebar2 & Finish reinforcement for the top flange and webs $\left(2^{\text {nd }}\right.$ stage rebar $)$ \\
\hline & Casting & Concrete casting for both $1^{\text {st }}$ and $2^{\text {nd }}$ stages \\
\hline & Curing & Curing for both $1^{\text {st }}$ and $2^{\text {nd }}$ stages \\
\hline \multirow{5}{*}{ 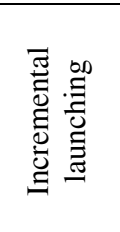 } & InstallTendons & Tendons installation into prestressing ducts \\
\hline & Stressing & Prestressing of tendons, first stage of longitudinal tendons and transversal tendons \\
\hline & Dismantle & Dismantling and lowering of formwork \\
\hline & SurfaceCheck & Surface check and finishing \\
\hline & DeckPushing & Pushing for the whole bridge deck \\
\hline
\end{tabular}




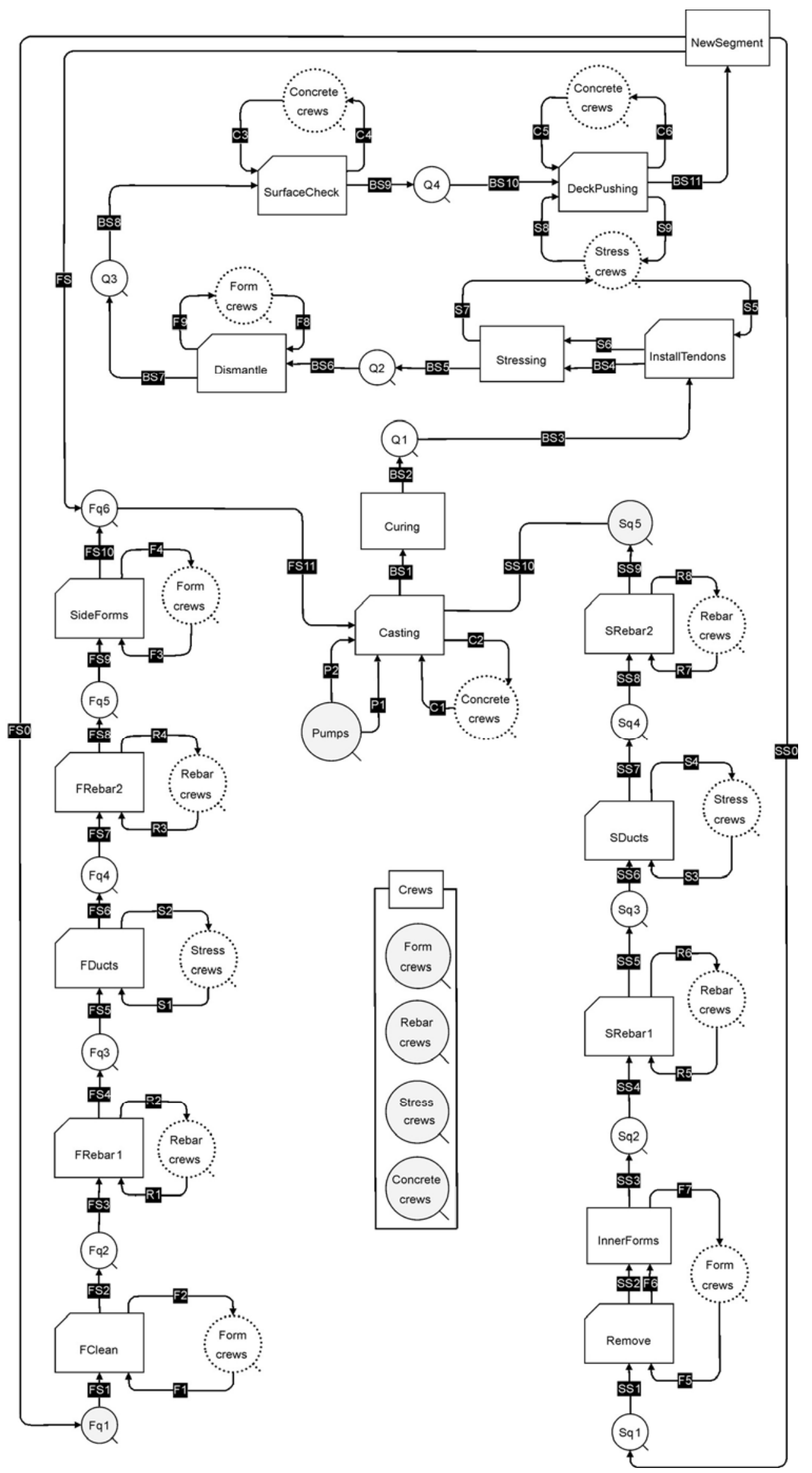

Fig 5. Simulation network for multiple forms method 
Flow control statements and dummy elements are used in modelling incremental launching construction technique using multiple forms method requires both. At the beginning of deck construction, the first stage involves execution of the bottom flange and bottom stubs of webs for the first segment only. This is accomplished via using two Queues, named Fq1 and Sq1. In the first cycle, Fq1 is assigned a single segment resource while assigning null resource in Sq1. As such, only the tasks of the first stage are executed. To perform casting task, a single segment resource is assigned in Sq5 Queue that exists in the second stage fabrication path. For subsequent cycles, both the first and second tasks are performed simultaneously, except for the final cycle which involves the execution of the second stage fabrication for the last segment. Therefore, the first stage tasks in the simulation network are frozen as the following control statements:

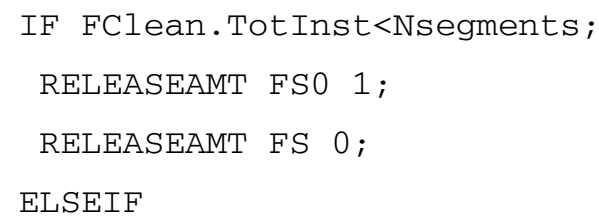

The above control statements release the resources that emerge from the dummy Normal element, named NewSegment, which receives only one Segment resource at a time. Releasing Segment resource to Arcs (FSO, FS, and SS) depends on the current construction status. If there are remaining segments that need to be passed through the first stage fabrication (ie, FClean.TotInst< Nsegments), the Arc FS is frozen while Arc FSO is engaged with a Segment resource. As such, the tasks of the first and second stages are performed simultaneously in a typical cycle (ie two successive segments). The tasks are continuously executed until all segments are finished with the first stage fabrication (ie FClean. TotInst $>=$ Nsegments). In this case, FSO Arc is frozen, while FS Arc is engaged with the last Segment resource. This leads to vanishing Segment resources from Fq1 Queue, which represents the first Queue in the first stage path, preventing the first stage tasks from being launched.

\section{Case study}

To validate the proposed simulation model, data from an actual project were utilised. The case considers the construction of the $15^{\text {th }}$ May bridge, located in Cairo, Egypt. The bridge was constructed using incremental launching technique with a single form as shown in Fig 6 . It consists of 35 equal spans; each has a length of $25 \mathrm{~m}$. The total length of the bridge is $875 \mathrm{~m}$ which is considered too long to be constructed and pushed using a single fabrication area. Therefore, the scope of work was divided into two zones, Zone I with a $550 \mathrm{~m}$ length and Zone II with a $325 \mathrm{~m}$ length. Each zone is fabricated and pushed using its respective fabrication area, producing typical segments that have a length of $12,5 \mathrm{~m}$. As such, 44 and 26 segments were fabricated for Zone I and Zone II, respectively. Duration of processes tasks are listed in Table 4. It should be noted that the work in the project was limited to 8 working hours per day.

Bridge data were fed to the simulation model, conducting 100 simulation replications to calculate the duration of deck construction in each zone. Simulation experiment was conducted in two stages. First, segments fabrication was modelled for each zone (Operation 2 in Fig 1). Zone I consumed longer duration with a mean value equals 397,1 days. As such, the production rate of segments obtained from the simulation model is 9,03 days/segment, compared to 10 days/segment as actual production in $15^{\text {th }}$ May bridge. Second, the output obtained from the first stage was used to model the whole construction of bridge deck (simulation network depicted in Fig 1) using data listed in Table 5. The average duration of bridge deck construction is estimated to be 425,3 days with a standard deviation of 5,4 days.

The case is also considered to be constructed using multiple forms method as per the data listed in Table 6. The duration of casting yard preparation and set-up of bridge deck are modelled using the values, by the single form method (Table 5). A sensitivity analysis was performed to evaluate the system performance under different combinations of resources. The involved resources are four labour crews (formwork, reinforcement, stressing, and concrete crews) and concrete pump equipment. Concrete labour crew and pump are not considered in the analysis since their change does not affect production rate. Therefore, a concrete crew and single pump are allocated for all considered combinations. Table 7 lists eight combinations of crews and their estimated mean and standard deviation values for segment fabrication and deck construction durations.

Using the multiple forms method (with minimum number of crews) decreases the duration of segment fabrication to be 374,43 days with associated production rate of 8,51 days/segment. It should be noted that increasing the number of labour crews shortens the fabrication duration as per Table 6 . The results indicate that the deck construction is very sensitive to the rebar crew. A compression in segment fabrication duration of 37,39 days is obtained by doubling the rebar crew. The shortest durations are obtained by doubling the number of all crews (formwork, reinforcement, stressing, and concrete crews). In this combination, the estimated durations for segment fabrication and deck construction are 330,14 and 359,09 days, respectively. It has a production rate of 7,5 days/segment. 


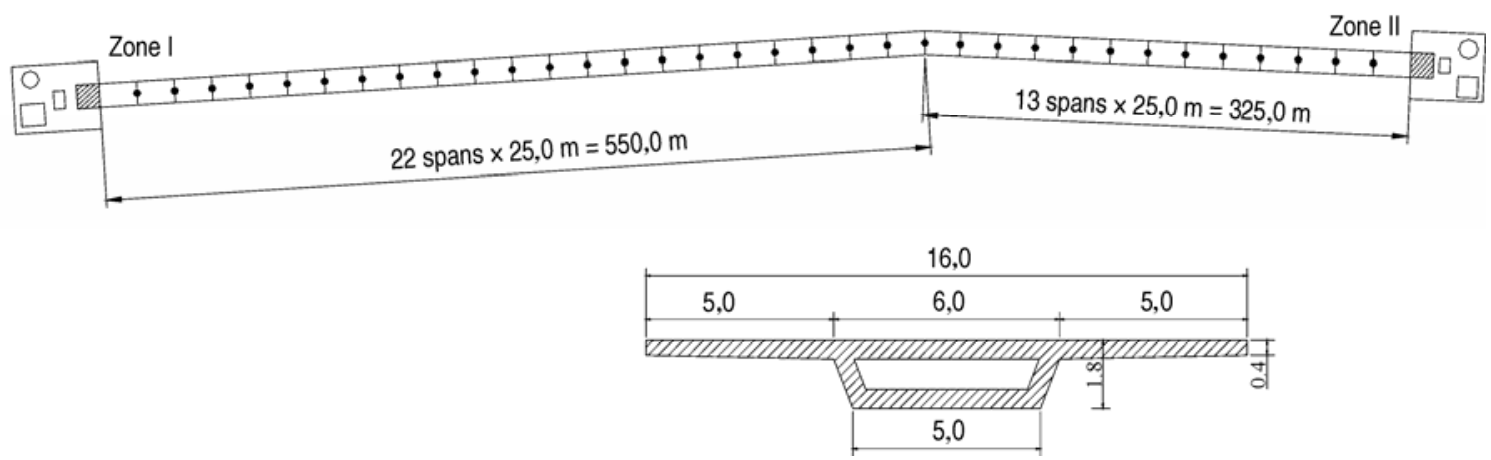

Fig 6. $15^{\text {th }}$ May bridge: layout and cross-section

Table 4. Durations of single form method tasks

\begin{tabular}{|c|c|c|}
\hline Process & Task & Duration (min) \\
\hline \multirow{7}{*}{ 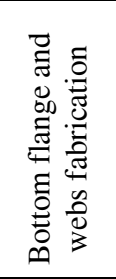 } & Cleaning, raising, aligning, and grading of forms & $\mathrm{N}(120,60)$ \\
\hline & Placement of $1 / 2$ reinforcement for the bottom flange and webs $\left(1^{\text {st }}\right.$ stage rebar $)$ & $\operatorname{Pg}(300,360,420)$ \\
\hline & Placement of tendons for the bottom flange and webs $\left(1^{\text {st }}\right.$ stage tendons $)$ & $\mathrm{N}[130,60]$ \\
\hline & Finish reinforcement for the bottom flange and webs $\left(1^{\text {st }}\right.$ stage rebar $)$ & $\operatorname{Pg}[270,360,420]$ \\
\hline & Erection of inner side forms & $\mathrm{U}[60,240]$ \\
\hline & Concreting the first phase $\left(1^{\text {st }}\right.$ stage casting $)$ & $\mathrm{T}[270,360,420]$ \\
\hline & Curing the first phase $\left(1^{\text {st }}\right.$ stage curing $)$ & $\mathrm{U}[360,600]$ \\
\hline \multirow{7}{*}{ 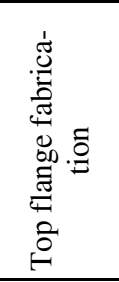 } & Removing of inner side forms & $\mathrm{U}[45,120]$ \\
\hline & Pulling inner side forms & $\mathrm{U}[30,90]$ \\
\hline & Placement of $1 / 2$ reinforcement for the top flange ( $2^{\text {nd }}$ stage rebar $)$ & $\operatorname{Pg}[300,400,600]$ \\
\hline & Placement of tendons for the top flange $\left(2^{\text {nd }}\right.$ stage tendons $)$ & $\mathrm{N}[120,50]$ \\
\hline & Finish reinforcement for the top flange $\left(2^{\text {nd }}\right.$ stage rebar $)$ & $\operatorname{Pg}[300,400,600]$ \\
\hline & Concreting the second phase ( $2^{\text {nd }}$ stage casting $)$ & $\mathrm{T}[360,420,480]$ \\
\hline & Curing the second phase $\left(1^{\text {st }}\right.$ stage curing $)$ & $\mathrm{U}[360,600]$ \\
\hline \multirow{5}{*}{ 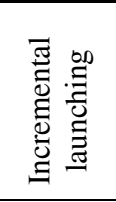 } & Tendons installation into pre-stressing ducts & $\mathrm{U}[30,120]$ \\
\hline & Pre-stressing tendons, first stage of longitudinal tendons and transversal tendons & $\mathrm{U}[60,180]$ \\
\hline & Dismantling and lowering formwork & $\mathrm{U}[90,240]$ \\
\hline & Surface check and finishing & $\mathrm{U}[15,60]$ \\
\hline & Incremental launching & $\mathrm{N}[120,45]$ \\
\hline
\end{tabular}

Note:

$U[a, b]$ : Uniform distribution; $a$ is the lower value; $b$ is the higher value.

$T[a, b, c]$ : Triangle distribution; $a$ is the lower value; $b$ is the mode value; $c$ is the higher value.

$N[a, b]$ : Normal distribution; $a$ is the mean value; $b$ is the standard deviation.

$\operatorname{Pg}[a, b, c]$ : Perry \& Grieg Beta distribution; $a$ is the value at $5 \% ; b$ is the mode value; $c$ is the value at $95 \%$.

Table 5. Duration of incremental launching tasks

\begin{tabular}{l|l|l}
\hline \multicolumn{1}{c|}{ Operation } & \multicolumn{1}{|c}{ Task } & \multicolumn{1}{c}{ Duration } \\
\hline Preparation & Casting yard preparation & $\mathrm{U}(13,25)$ days \\
\hline Deck fabrication & Output from first simulation stage & $\mathrm{N}(397.1,3.2)$ days \\
\hline \multirow{5}{*}{ Set-up of bridge deck } & Lifting of bridge deck & $\mathrm{U}(16,32)$ hrs \\
\cline { 2 - 3 } & Removing temporary bearings & $\mathrm{U}(6,12)$ hrs \\
\cline { 2 - 3 } & Installing permanent bearings & $\mathrm{U}(4,12)$ hrs \\
\cline { 2 - 3 } & Bearings grouting injection & $\mathrm{U}(4,8)$ hrs \\
\cline { 2 - 3 } & Bearings grouting curing & $\mathrm{U}(6,10)$ hrs \\
\cline { 2 - 3 } & Lowering of bridge deck & $\mathrm{U}(8,16)$ hrs \\
\cline { 2 - 3 } & Final pre-stressing & $\mathrm{U}(8,16)$ hrs \\
\hline
\end{tabular}

Note: $\mathrm{U}$ and $\mathrm{N}$ are uniform and normal distributions, respectively. 
Table 6. Durations of multiple forms method tasks

\begin{tabular}{|c|c|c|}
\hline Process & Task & Duration (min) \\
\hline \multirow{12}{*}{ 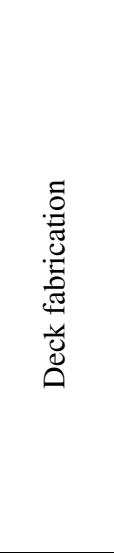 } & Cleaning, raising, aligning, and grading of first form & $\mathrm{N}(120,60)$ \\
\hline & Placement of $1 / 2$ reinforcement for the bottom flange and bottom stubs of webs ( $1^{\text {st }}$ stage rebar) & $\operatorname{Pg}(300,360,420)$ \\
\hline & Placement of tendons for the bottom flange and bottom stubs of webs $\left(1^{\text {st }}\right.$ stage tendons $)$ & $\mathrm{N}[130,60]$ \\
\hline & Finish reinforcement for the bottom flange and bottom stubs of webs $\left(1^{\text {st }}\right.$ stage rebar $)$ & $\operatorname{Pg}[270,360,420]$ \\
\hline & Erection of inner side forms & $\mathrm{U}[60,240]$ \\
\hline & Removing inner side forms & $\mathrm{U}[45,120]$ \\
\hline & Pulling inner top forms & $\mathrm{U}[30,90]$ \\
\hline & Placement of $1 / 2$ reinforcement for the top flange and webs ( $2^{\text {nd }}$ stage rebar $)$ & $\operatorname{Pg}[300,400,600]$ \\
\hline & Placement of tendons for the top flange and webs ( $2^{\text {nd }}$ stage tendons $)$ & $\mathrm{N}[120,50]$ \\
\hline & Finish reinforcement for the top flange and webs $\left(2^{\text {nd }}\right.$ stage rebar $)$ & $\operatorname{Pg}[300,400,600]$ \\
\hline & Concrete casting for both $1^{\text {st }}$ and $2^{\text {nd }}$ stages & $\mathrm{T}[360,420,480]$ \\
\hline & Curing for both $1^{\text {st }}$ and $2^{\text {nd }}$ stages & $\mathrm{U}[960,1920]$ \\
\hline \multirow{5}{*}{ 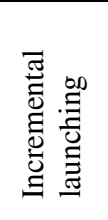 } & Tendons installation into pre-stressing ducts & $\mathrm{U}[30,120]$ \\
\hline & Prestressing tendons, first stage of longitudinal tendons and transversal tendons & $\mathrm{U}[60,180]$ \\
\hline & Dismantling and lowering formwork & $\mathrm{U}[90,240]$ \\
\hline & Surface check and finishing & $\mathrm{U}[15,60]$ \\
\hline & Pushing for whole bridge deck & $\mathrm{N}[120,45]$ \\
\hline
\end{tabular}

Note: $\mathrm{U}, \mathrm{T}, \mathrm{N}$ and $\mathrm{Pg}$ are uniform, triangle, normal, and pertpg distributions, respectively.

Table 7. Results of sensitivity analysis

\begin{tabular}{|c|c|c|c|c|c|c|c|}
\hline \multirow[t]{2}{*}{ ID } & \multirow[t]{2}{*}{ Form crews } & \multirow[t]{2}{*}{ Rebar crews } & \multirow{2}{*}{$\begin{array}{l}\text { Stressing } \\
\text { crews }\end{array}$} & \multicolumn{2}{|c|}{$\begin{array}{l}\text { Segment fabrication } \\
\text { Duration (days) }\end{array}$} & \multicolumn{2}{|c|}{$\begin{array}{l}\text { Total deck construction } \\
\text { Duration (days) }\end{array}$} \\
\hline & & & & Mean & $\sigma$ & Mean & $\sigma$ \\
\hline 1 & 1 & 1 & 1 & 375 & 4,5 & 405 & 6,1 \\
\hline 2 & 2 & 1 & 1 & 379 & 4,3 & 408 & 5,8 \\
\hline 3 & 1 & 2 & 1 & 338 & 4,6 & 366 & 5,8 \\
\hline 4 & 2 & 2 & 1 & 333 & 4,1 & 362 & 5,2 \\
\hline 5 & 1 & 1 & 2 & 376 & 3,7 & 405 & 5,2 \\
\hline 6 & 1 & 2 & 2 & 337 & 4,1 & 365 & 5,1 \\
\hline 7 & 2 & 1 & 2 & 378 & 4,4 & 407 & 5,6 \\
\hline 8 & 2 & 2 & 2 & 331 & 4,1 & 360 & 6,3 \\
\hline
\end{tabular}

\section{Conclusions}

This paper presented a model for construction of bridges using incremental launching technique. The model applies computer simulation to take into consideration uncertainty and interaction amongst involved resources. It supports two construction methods: single form and multiple forms. In the former method, only one segment is executed at construction time, whereas the latter method allows execution of two successive segments simultaneously. The typical cycle of segment fabrication, by two methods, consists of three processes: 1) bottom flange and webs fabrication, 2) top flange fabrication, and 3) prestressing. The paper described the design considerations made to maintain the logic and inference of simulation process by Arc elements and flow control statements. Arc elements are used to model the direction of resource entity flow between a task and its predecessors and successors tasks, whereas flow control statements are used to control tasks' initiations, resources draw amounts, resources release amounts, and any conditional logical aspect related to the construction work. An actual case study example was presented to examine the results of the developed model and illustrate its capabilities in modelling single form and multiple forms methods. A sensitivity analysis was conducted for the case to study the impact of assigned recourses in the estimated durations of segment fabrication and deck construction. The results of the study reveal that the deck construction is very sensitive to rebar crew.

\section{References}

$1 \mathrm{PMBOK}^{\odot}$. A guide to the project management body of knowledge. $3^{\text {rd }}$ ed, Project Management Institute, Inc., Pennsylvania, USA, 2004. 388 p.

2. SHANNON, R. E. Introduction to simulation. In Proc of the 1992 Winter Simulation Conference, Arlington, VA, USA, 1992, p. 65-73.

3. ABOURIZK, S. M. and HAJJAR, D. A framework for applying simulation in construction. Canadian Journal of Civil Engineering, 5(3), 1998, p. 604-617. 
4. SAWHNEY, A. and ABOURIZK, S. M. Computerized tool for hierarchical simulation modeling. Journal of Computing in Civil Engineering, 10(2), 1996, p. 115-124.

5. OLOUFA, A.; IKEDA, M. and NGUYEN, T. Resourcebased simulation libraries for construction. Automation in Construction, 7(4), 1998, p. 315-326.

6. TOURAN, A. Integration of simulation with expert systems. Journal of Construction Engineering and Management, 116(3), 1990, p. 480-493.

7. PRITSKER, A. A. B.; O'REILLYAND, J. J. and LAVAL, D. K. Simulation with Visual SLAM and AweSim. John Wiley \& Sons, Inc., New York, NY, 1997. 811 p.

8. CRAIN, R. C. Simulation using GPSS/H. In Proc of the 1997 Winter Simulation Conference, Atlanta, GA, USA, 1997, p. 567-573.

9. HALPIN, D. W. and RIGGS, L. S. Planning and analysis of construction operations. John Wiley \& Sons, Inc., New York, NY, 1992. 400 p.
10. MARTINEZ, J. C. STROBOSCOPE - State and resource based simulation of construction processes. $\mathrm{PhD}$ thesis, University of Michigan, 1996. 518 p. (available at http://strobos.ce.vt.edu)

11. MARZOUK, M. and MOSELHI, O. An object - oriented model for earthmoving operations. Journal of Construction Engineering and Management, 129(2), 2003, p. 173181.

12. PODOLNY, W. and MULLER, J. M. Construction and design of prestressed concrete segmental bridges. John Wiley \& Sons, Inc., New York, NY, 1982. 561 p.

13. NISEE. Incrementally launched bridges. University of California, Berkeley, 1997. (available at

http://nisee.berkeley.edu/leonhardt/html/incrementally_lau nched_bridges.html).

\section{LAIPSNIŠKAI UŽSTUMIAMŲ TILTŲ STATYBOS PROCESO KOMPIUTERINIS MODELIAVIMAS M. Marzouk, H. Zein El-Dein, M. El-Said}

Santrauka

Tiltų statybos procesas susijęs su daugeliu neapibréžtumų, kurie atsiranda dẻl išteklių stygiaus, irangos gedimų ir (arba) darbo aplinkos. Tiltu statybos technologijos gali būti suskirstytos į šešias pagrindines kategorijas: 1) betonavimas statybos vietoje ant irengtų klojinių, 2) montavimas kabamuoju metodu, 3) betonavimas statybos vietoje, taikant perstatomuosius klojinius, 4) montavimas, užstumiant sijas, 5) montavimas kabamuoju pusiausviruoju metodu ir 6) montavimas, taikant laipsnišką išilgini užstūmimą. Pastarojoje technologijoje iki minimumo sumažinamas klojiniu poreikis. Be to, tilto perdangos segmentų gamyba ir montavimas atliekamas statybos aikštelèje, kurioje irengiami klojiniai, betono gamybos ir tiekimo i parengtus klojinius mazgai. Šiame straipsnyje pateikiamas specialios paskirties modelis neapibrèžtumams tiltu statybos procese įvertinti. Modelyje įvertinta laipsniško užstūmimo metodu statomiems tiltams reikalingų skirtingų išteklių tarpusavio sąveika. Straipsnyje aprašomi du statybos metodai (viena forma ir daug formu), kurie taikomi segmentams gaminti. Pasiūlytame modelyje panaudota STROBOSCOPE skaičiavimo programa, sukurta Visual Basic 6.0 programavimo kalba. Pasiūlytojo modelio veiksmingumui pagristi pateiktas praktinio taikymo pavyzdys.

Reikšminiai žodžiai: projektavimas, tilto statyba, kompiuterinis modeliavimas, laipsniško užstūmimo metodas, planavimas, neapibréžtumai.

Mohamed MARZOUK. Assistant Professor at Dept of Structural Engineering, Faculty of Engineering, Cairo University. BSc and MSc in Civil Engineering from Cairo University in 1995 and 1997, respectively. PhD from Concordia University in 2002. Member of Egyptian Code of Practice for Construction Management, and Quality Control Committee, National Organisation for Civilisation Reformation, Ministry of culture. His research interests include simulation and optimisation of construction processes, O-O simulation, fuzzy logic and its applications in construction, risk analysis, and decision analysis.

Hisham ZEIN EL-DEIN. Assistant Lecturer at Dept of structural engineering, Faculty of engineering, Cairo University. BSc and MSc in Structural Engineering from Cairo University in 2003 and 2006, respectively. His research interests include simulation of construction operations, optimisation applications, construction technologies, and construction productivity.

Moheeb EL-SAID. Professor of construction engineering and management at Dept of structural engineering, Faculty of engineering, Cairo University. A member of Egyptian code of practice for construction management, and chairman of Quality control committee, National organisation for civilisation reformation, Ministry of culture. His research interests include productivity, scheduling, risk assessment, life cycle costs, and simulation. 